\title{
Wymiary zależności a formy autonomii i autarkii polskiej politologii: Odpowiedź na komentarze
}

\begin{abstract}
STRESZCZENIE: Niniejszy artykuł stanowi jeden z głosów w dyskusji nad półperyferyjnym charakterem systemów produkcji naukowej, dla której pretekstem była publikacja książki Gra peryferyjna Tomasza Warczoka i Tomasza Zaryckiego. Autorzy odpowiadają w nim na dwa głosy polemiczne w dyskusji, skupiając się na zagrożeniach materialistycznej korekty teorii Pierre'a Bourdieu i hegemonicznej pozycji inteligencji jako czynnika kształtującego polskie pole nauk społecznych.
\end{abstract}

SŁOWA KLUCZOWE: gra peryferyjna, centrum, peryferia, nauki społeczne, Bourdieu, Wallerstein

W komentarzach do naszego tekstu „Polskie nauki polityczne w perspektywie globalnej: paradoksy ewoluującej peryferyjności” (Warczok i Zarycki 2018), będącego jednocześnie pewnym podsumowaniem naszej obszerniejszej pracy książkowej (Warczok i Zarycki 2016), Jakub Krzeski i Krystian Szadkowski (2018) oraz Dominik Antonowicz (2018) zawarli wiele ciekawych uwag i krytyk, które pozwalają na doprecyzowanie tych elementów, które przedstawiliśmy być może zbyt pobieżnie oraz wyartykułowanie tych wyjaśnień, które przeoczyliśmy.

Zacznijmy od użytych przez nas narzędzi analitycznych. Z pewnością, jak wskazują Krzeski i Szadkowski (2018), połączenie czy też wzajemne uzupełnienie teorii Bourdieu i Wallersteina, które próbowaliśmy przeprowadzić, nie są symetryczne. Raczej rozszerzamy ujęcie Bourdieu przez dodanie „światowego” wymiaru teorii Wallersteina (podział na centrum, peryferie i półperyferie) niż odwrotnie. Sam Wallerstein co prawda zajmował się nauką jako taką, jej kondycją i historycznym rozwojem (Wallerstein 2004), jednak wszystko to zarysowane było w bardzo szerokim ujęciu i nie stanowiło przedsięwzięcia z zakresu socjologii nauki sensu stricte 
(co z kolei my chcieliśmy uczynić). Dlatego też konsekwentnie idziemy tropem Bourdieu, pozwalając sobie, tam gdzie to konieczne na uzupełnienia i korekty.

I właśnie Bourdieu i jego wielowymiarowa wizja rzeczywistości społecznej odpowiada, do pewnego stopnia, na zarzut Krzeskiego i Szadkowskiego (2018), który dotyczy braku sproblematyzowania relacji między pozycją ekonomiczną danego kraju (miejsca w systemie-świecie) a pozycją (w tym przypadku pół-peryferyjną) danego pola naukowego (co ciekawe Antonowicz (2018) twierdzi, że jedno łączymy wprost z drugim, pozycja ekonomiczna określonego państwa ma wprost przekładać się na jego pozycję w światowej hierarchii nauki). Krzeski i Szadkowski (2018) nazywają to koniecznością „materialistycznej korekty” Bourdieu (przez zastosowanie pewnych rozwiązań zaproponowanych przez Wallersteina). Gdyby pójść tym tropem, z pewnością osiągnęlibyśmy wspomnianą wcześniej symetrię, ale niestety zaprowadziłoby to nas na manowce ekonomicznego redukcjonizmu, o marksistowskiej tym razem proweniencji (Burawoy 2018). Teoria Bourdieu koryguje częsty błąd ekonomizmu (występującego w wersji neoliberalnej lub marksistowskiej) sprowadzający rzeczywistość społeczną wyłącznie do gry interesów materialnych („ekonomicznych” w rozumieniu teorii ekonomicznej). Podczas gdy, jak przekonuje Bourdieu (2006), w świecie nowoczesnym występuje wielość pól społecznych, nie tylko pole ekonomiczne (z naczelną zasadą bussines is bussines) - które, zauważmy, samo w sobie jest nowoczesnym wynalazkiem - ale także pola produkcji kulturowej kierujące się zupełnie innymi zasadami (pole sztuki, literatury, nauki). Nie oznacza to odejścia w stronę idealizmu, gdyż nawet w świecie sztuki obowiązują określone interesy (Bourdieu 2001), samo zaś pole sztuki, podobnie jak pole nauki jest zhierarchizowane i podzielone wedle określonej dystrybucji kapitałów (przede wszystkim kapitału uznania, prestiżu, czyli kapitału symbolicznego). Inaczej mówiąc, w nowoczesnym świecie występuje wielość kapitałów (każde pole ma swój kapitał), same zaś pola produkcji kulturowej, w tym pole naukowe, posiadają pewien stopień wywalczonej autonomii, zwłaszcza wobec interesów politycznych i, co w tym kontekście szczególnie ważne, ekonomicznych. W konsekwencji pola ekonomiczne i pola kulturowe rozwijają się w relatywnym odizolowaniu, jedno nie musi przekładać się na drugie. I tak w epoce Renesansu światowym centrum ekonomicznym była Wenecja, kulturowym zaś Florencja, w okresie późniejszym analogiczne centra przeniosły się z jednej strony do Londynu (centrum industrializacji), z drugiej do Paryża (centrum literatury i sztuki) (Casanova 2017). Także dzisiaj nie można w prosty sposób sprowadzać hegemonii ekonomicznej do hegemonii kulturowej czy naukowej, gdyż są to, do pewnego stopnia, odrębne logiki wynikające z bardziej lub mniej odmiennych trajektorii (historii) poszczególnych pól. Przykładowo PKB per capita Szwecji wynosi $\$ 54,010$, Francji zaś $\$ 38,647$, podczas gdy produkcja kulturowa tego ostatniego kraju (mierzona liczbą tłumaczonych w świecie książek, dystrybuowanych w świecie 
filmów, zwłaszcza tych nagradzanych na światowych festiwalach) jest nieporównywalnie większa niż pierwszego. Francja stoi wyżej w hierarchii kultury (pól produkcji kultury) niż Szwecja mimo znacznie mniejszej zamożności pola kultury. Wynika to nie tyle z wielkości tego kraju, co ze specyficznej trajektorii francuskiego pola kultury (przede wszystkim literatury i sztuki), hegemonii, jaką zaczął sprawować Paryż właściwie od początku ery nowoczesnej, a która oddana została (ale tylko do pewnego stopnia) na rzecz Nowego Jorku (np. Paryż nadal jest centrum autonomicznego bieguna globalnego pola filmowego, zob. Casanova 2017).

Co ważne, każde z wyodrębnionych historycznie pól posiada swoją trajektorię i musi być analizowane oddzielnie. Krzeski i Szadkowski podają przykład dynamicznego rozwoju azjatyckiej, a zwłaszcza chińskiej matematyki, co ma podważać generalną naukową hegemonię Stanów Zjednoczonych. Być może w polu matematyki podobne procesy mają miejsce, jednak wymagałoby to osobnej analizy, która nie sprowadzałaby się wyłącznie do prostego kryterium ilościowego, np. odsetka artykułów danego kraju w globalnym korpusie tematycznym, nawet tych wysoko cytowanych (przed czym przestrzega np. Gingras 2013). Istotna jest, jak w każdej analizie pola, także narodowa czy kontynentalna dystrybucja nagród (np. medal Fieldsa jak dotąd otrzymał tylko jeden badacz afiliowany na uniwersytecie azjatyckim, Japończyk Shigefumi Mori z Kyoto) oraz kierunki migracji naukowców (Maryam Mirzakhani, pierwsza kobieta, która otrzymała tę prestiżową nagrodę urodziła się i kształciła w Iranie, ale doktorat otrzymała już w Stanach Zjednoczonych, gdzie do końca życia pracowała).

Jednak fakt, iż poszczególne pola odznaczają się specyficznymi trajektoriami, nie oznacza, że są one zupełnie niezależne od siebie, zwłaszcza od pól ekonomicznych. Zaakcentować należy, że cały czas mówimy o relatywnej autonomii pól naukowych, co oznacza, że pewna zależność istnieje, nie jest jednak zwykle (przy zaawansowanym rozwoju pola) bezpośrednia. $W$ ten sposób w państwach światowego centrum, wysoko rozwiniętych i zamożnych, istnieje stabilna baza finansowania nauki, która daje oczywistą przewagę tamtejszym polom naukowym wobec pól (pół)peryferyjnych. Co ważne jednak, jak wskazuje z kolei Wallerstein (2011), kraje centrum charakteryzują się także, czego nie dostrzegają liberalni ekonomiści, silnymi instytucjami państwowymi będącymi ważnym czynnikiem mediującym w poszczególnych narodowych polach władzy - między siłami czysto ekonomicznymi (kapitalistycznymi przedsiębiorstwami) a polami naukowymi. Bez nich nauka utraciłaby autonomię i została podporządkowana biznesowi, w konsekwencji zaś ulegając stagnacji. Podobny łańcuch zależności tłumaczy półperyferyjną pozycję polskich nauk społecznych: nie tylko chodzi o pozycję polskiej gospodarki (mierzoną PKB per capita, miejscem w światowym łańcuchu produkcji, bilansem handlowym itd.), ale także o słabe instytucje państwa, które w okresie transformacji zrezygnowały właściwie 
z jakiejkolwiek polityki naukowo-edukacyjnej, poddając dużą część tego obszaru prywatyzacji. W efekcie, jak pokazał cytowany przez Krzeskiego i Szadkowskiego Marek Kwiek (2012), nastąpiło przekierowanie funkcjonowania pola z działalności naukowo-dydaktycznej w silnie dydaktyczną, a więc, mówiąc naszym językiem, dokonała się w wymiarze krajowym poważna utrata autonomii na rzecz rynku (edukacyjnego).

Wszelako, jak argumentujemy, uzasadnione jest w tym kontekście odróżnienie co najmniej dwu wymiarów autonomii polskiego pola nauk społecznych, a w szczególności politycznych. Obok bowiem wspomnianego wymiaru krajowego, mówić można o wymiarze międzynarodowym, w którym polskiej politologii, i jest to warte zastanowienie, udało się zachować paradoksalną autonomię w globalnym polu nauk politycznych. Polscy politolodzy, jak pokazaliśmy w książce, poza kilkoma wyjątkami właściwie nie uczestniczą w światowej grze, jednak z powodzeniem rozwijają własną (uproszczoną) metodologię, odrębną od tego, co robi się nie tylko w USA, ale w polach zachodniej Europy. Cytują przede wszystkim swoich kolegów (i konkurentów) w lokalnym polu, nie czyniąc wysiłków w kierunku importu idei zachodnich (np. przez tłumaczenia książek, podręczników). Polegają na własnych zasobach, oferując studentom własne produkcje. Rzecz jest zaskakująca, gdyż podważa strukturalne zasady gry w nauce światowej. Uważa się bowiem, na co wskazują znane badania (Gingras 2002), że pozycję autonomiczną uzyskują jedynie pola hegemoniczne, czego najwyraźniejszym przykładem są Stany Zjednoczone (badacze stamtąd cytują przede wszystkim swoich kolegów, relatywnie rzadko wchodzą w kolaborację z badaczami z innych krajów, nie są też zainteresowani ideami wypracowywanymi na peryferiach, o czym świadczy znikoma liczba książek tłumaczonych w Stanach Zjednoczonych z języków peryferyjnych, zob. Sapiro 2012). Polskie pole politologiczne, z gruntu półperyferyjne, zaprzecza tej zasadzie. Różnica polega oczywiście na tym, że amerykańska autonomia połączona jest z hegemonią (wpływem na innych), polska autonomia oznacza odosobnienie, zbudowanie bariery, społecznej i symbolicznej wobec centrum. Być może więc trafniejszym określeniem dla usytuowania polskiej politologii w przestrzeni światowej byłaby „autarkia”. Yves Gingras (2002), opisując przypadek amerykańskiej nauki, wskazał, że używać można tego określenia zamiennie, zależnie od stanowiska politycznego (hołdujący zasadzie niezależności lokalnej nauki „nacjonaliści” mówiliby o autonomii, podczas gdy „kosmopolici” krytykowaliby taką sytuację jako autarkię). My jednak sądzimy, czego nie wyartykułowaliśmy w książce, że istnieje zasadnicza różnica między tym dwoma stanami. Autarkia, jak wiadomo, oznacza samowystarczalność, a więc zamknięcie nie tylko na wpływy zewnętrzne, ale możliwość wpływu na to, co znajduje się na zewnątrz (nie tylko nie ma potrzeby importu, ale także eksportu - w tym przypadku importu-eksportu idei). Autonomia oznaczałaby relatywną samowystarczalność (brak lub ograniczony import), ale połączony z ekstensywnym eksportem. 
Rysuje się oczywiście pytanie o społeczne warunki tak rozumianej autarkii. Kluczowy zdaje się być wystarczająco szeroki rynek wewnętrzny wsparty stabilnymi instytucjami. W przypadku polskiej politologii chodzi przede wszystkim o rynek edukacyjny, który rozwinął się wraz z boomem edukacyjnym końca lat $90 . \mathrm{XX}$ wieku i początku lat dwutysięcznych. Rynek ten, jak każdy inny, nie pojawił się spontanicznie, ale został skonstruowany między innymi poprzez praktyki dyskursywne - narzucone wizje świata samych naukowców (,społeczeństwo obywatelskie”, „gospodarka oparta na wiedzy" i wynikające rzekomo z tego zapotrzebowanie na specjalistów $\mathrm{z}$ wykształceniem wyższym). W ostatnich latach praktyki te ulegały rekonfiguracji celem podtrzymania popytu na rynku edukacyjnym (zamiast politologii „bezpieczeństwo państwa”, „bezpieczeństwo wewnętrzne” i inne tego typu kierunki studiów).

Widać jednak, że budowanie pola relatywnie „,autarkicznego” w wymiarze międzynarodowym ma swoją cenę i wiąże się głównie z nieformalnym ograniczeniem autonomii pola politologicznego wobec lokalnego pola władzy, to znaczy, z jednej strony, z podporządkowaniem, przynajmniej częściowym, interesom ekonomicznym wymogom rynku edukacyjnego, z drugiej zaś strony z pośrednim podporządkowaniem interesom politycznym pola władzy ${ }^{1}$. Ze względu na ekonomiczną zależność pola nauk społecznych, to, co musi ono oddać, to - znowu, przynajmniej częściowo tematyka badań (politolodzy muszą teraz poświęcić większą uwagę sprawom „bezpieczeństwa państwa" czy marketingu). W polu relatywnie autonomicznym temat badań oraz jego generalne kryteria funkcjonowania są sprawą jego uczestników, w analizowanym przypadku - jak widać - jest inaczej. Co ważne, w autonomicznym polu jego uczestnicy kontrolują także czas, dysponują tym, co Platon określał mianem skholè, czyli „czasem wolnym”, czasem przeznaczonym na wolną refleksję (na temat tego konsekwencji, zob. Bourdieu 2009). Jego ograniczenie pod wpływem czynników zewnętrznych (presja dydaktyki, ale także natychmiastowych komentarzy medialnych, rozmaite prace dodatkowe, „chałtury”, których znaczenie jest daleko większe niż sugerowałoby potoczne, frywolne określenie, zob. Warczok i Zarycki 2016) oznacza więc także ograniczenie autonomii. Warto więc zwrócić uwagę, że wbrew niektórym krytykom Ustawy 2.0 i innych projektów reformatorskich zmierzających

${ }_{1}$ Pole władzy jest meta-strukturą, przestrzenią występującą we wszystkich nowoczesnych społeczeństwach, która obejmuje górne, dominujące warstwy poszczególnych pól społecznych. Samo jest podzielone, jak wskazuje Bourdieu (1996) w wersji kanonicznej, tak jak pola, które w sobie zawiera: na część bardziej „autonomiczną”, czyli mniej zależną od polityki i pieniądza (gdzie lokują się: pole sztuki, literatury, nauki) oraz część „heteronomiczną” skupiającą pole ekonomiczne i polityczne. Pośrodku pola władzy w roli mediatora sytuuje się pole biurokratyczne, które można utożsamiać z instytucjami państwowymi (ministerstwami, urzędami itd.). Nasze badania (Warczok i Zarycki 2014) wskazały jednak, że na półperyferiach istnieje jeszcze inny wymiar podziału całego pola władzy: na część procentralną (prozachodnią, proeuropejską, „kosmopolityczną”, „liberalną” oraz antyzachodnią, eurosceptyczną, „narodową" i „konserwatywną”). 
ku „przybliżeniu nauki do realnej gospodarki”, którzy obawiają się tej perspektywy jako zagrożenia autonomii nauki, owa relacja jest już od dawna bardzo bliska. Zależność od pola ekonomicznego zlokalizowana została jednak głównie na poziomie indywidualnym i w dużym stopniu nieformalnym, a więc często niewidocznym na poziomie czysto instytucjonalnym² ${ }^{2}$. Jej ważnym aspektem jest tzw. wielopozycyjność inteligenckiej elity, znaczna część której zaangażowana jest w aktywność w wielu polach i wielu sektorach jednocześnie (publicznym i prywatnym, akademickim i administracyjnym, intelektualnym i politycznym, pozarządowym i korporacyjnym itp.). Ważną funkcją wielopozycyjności jest kompensacja w wymiarze materialnym względnie niskich pensji podstawowych w nauce i szkolnictwie wyższym, ale ceną jej są opisywane przez nas uwikłania i zależności (Dębska 2016).

Jeśli chodzi zaś o uzależnienie pola w wymiarze politycznym, to daniną, jaką musi ono składać, jest udział znaczącej części jego przedstawicieli w bezpośrednim legitymizowaniu interesów elit głównych obozów współczesnego polskiego pola władzy. Należy jednak podkreślić, że podobnie jak w wymiarze zależności ekonomicznej, nie jest to zwykle podległość zinstytucjonalizowana. Działa ona raczej na poziomie jednostek czy małych grup i ma charakter pośredni. Pole jako takie, a w szczególności poszczególne środowiska, zachowują bowiem względną niezależność od politycznych oczekiwań biurokracji państwowej, której trudno narzucać jest wprost swoje dyspozycje badaczom chronionym przez liczne samorządowe instytucje jak rady wydziału, senaty czy rady instytucji centralnych. Zaangażowanie się w realizację oczekiwań pola władzy zachodzi na poziomie indywidualnie uświadamianego poczucia obowiązku, misji czy interesu. I odnosi się zwykle raczej do spełniania oczekiwań określonych środowisk inteligenckich pola władzy niż jakiś instytucjonalizowanych struktur. Jednym z aspektów tego mechanizmu jest to, iż politolodzy angażują się dość licznie w mediach jako komentatorzy polityczni, a także dużą część swoich prac formalnie akademickich tworzą jako de facto polityczne komentarze i uzasadnienia określonych wyborów politycznych. Implikuje to wyraźny podział w polu według orientacji ideologicznych, który uznać można za w pewnym zakresie homologiczny do głównego podziału pola władzy i pola politycznego. Mówić tu więc można po prostu o efekcie upolitycznienia pola, które jednak przebiega nie w pełni symetrycznie do proporcji sił w polu politycznym, ponieważ w obrębie elit politologicznych zwolennicy orientacji konserwatywno-euro-sceptycznej znajdują się w zdecydowanej mniejszości. Warto jednak pochylić się bliżej na kwestią „licznych gorszących «romansów», w jakie

2 Interesującą poszlaką silnego wzrostu uzależnienia pola polskich nauk społecznych od pola ekonomicznego właśnie w momencie upadku komunizmu jest świadectwo Moniki Kostery (2018), która opisuje swoje doświadczenia z czasów studiów na Wydziale Zarządzania UW. Zgodnie z jej relacją po 1990 roku nastąpiło niejako fazowe przejście od kultury intelektualnych pasji panujących w jej środowisku do niesprzyjającej jakimkolwiek intelektualnym dyskusjom atmosfery powszechnej orientacji na indywidualne „dorabianie się”, głównie na indywidualnych zleceniach. 
z politycznymi partami z lubością wdali się badacze nauk politycznych”, jak pisze o nich obrazowo Dominik Antonowicz (2018). Autor ten przypisuje odpowiedzialność za te formy zaangażowania przede wszystkim rozwojowi mediów, a zwłaszcza całodobowych kanałów informacyjnych. Wspomina także o znaczeniu „kapitału medialnego" jako lokalnie bardziej atrakcyjnym zasobie od kapitału akademickiego mierzonego np. liczbą międzynarodowych cytowań. Warto jednak zwrócić uwagę, że rozwój mediów elektronicznych w ostatnich dekadach nie był w żadnym wypadku osobliwością Polski, natomiast stopień zaangażowania naukowców społecznych, a przynajmniej części ich elity w polu medialnym i polityczno-medialnym w naszym kraju wydaje się być znacząco wyższy od średniej krajów zachodnich, a także wielu innych krajów regionu. Na możliwe wytłumaczenia tego fenomenu wskazujemy w naszej książce, jednak korzystając z okazji, pozwolimy sobie rozwinąc ten wątek.

Otóż w naszym przekonaniu istotnym aspektem polskiej specyfiki jest szczególna, uprzywilejowana rola inteligencji, a w szczególności jej elit w hierarchii społecznej naszego kraju; pisaliśmy wcześniej nawet o ich hegemonicznej roli (Zarycki i Warczok 2014). Naukowcy społeczni, w szczególności ich elita, niejako z definicji są w Polsce częścią szczególnie uprzywilejowanych środowisk inteligenckich. To też czyni ich o wiele bardziej atrakcyjnymi dla mediów, a także polityków niż ich koledzy w innych państwach, w szczególności w Stanach Zjednoczonych czy w Europie Zachodniej. Nie jest bowiem tak, że politolodzy amerykańscy czy zachodnioeuropejscy nie czują pokusy medialnej popularności. Wielu z nich chętnie gromadziłoby również „medialny kapitał", demonstrując tym samym swoje zdolności oddziaływania na sferę publiczną oraz „przydatność” posiadanej czy też tworzonej przez nich wiedzy. Takie zaangażowania akademików są też często wbrew pozorom doceniane przez dużą część zachodnich uczelni. Nie są oni jednak zwykle tak atrakcyjni dla mediów w swoich krajach, jak dla rodzimych mediów atrakcyjni są polscy naukowcy, którzy przemawiają do nas zwykle z ekranów, łamów gazet czy portali internetowych nie tylko w roli specjalistów, ale przede wszystkim jako inteligenckie autorytety moralne. W krajach zachodnich w mediach goszczą zaś głównie względnie nieliczni naukowcy-celebryci, z drugiej zaś strony funkcje komentatorskie pełnią częściej analitycy niż uczeni niemający dodatkowego splendoru moralnych wyroczni. Większość badaczy pozostaje zaś zamknięta we względnie izolowanych świecie akademii i ma poważne trudności z zainteresowaniem swoimi pracami szerszych kręgów społecznych (Burawoy 2005).

Innym aspektem inteligenckiej hegemonii w Polsce jest znaczące podporządkowanie interesom elity inteligenckiej pełniącej kluczową rolę w polu władzy (choć obecnie niekoniecznie w polu sensu stricte politycznym) samego pola akademickiego, podobnie jak i wielu pól społecznych. Do momentu tzw. upadku komunizmu czy też wyjścia Polski z bloku krajów zależnych od ZSRR istotnym konkurentem inteligenckiej elity pozostawała tzw. nomenklatura. Może ona być określana jako elita 
polityczna realizująca program modernizacji kraju jako części autonomicznej wobec świata zachodniego tzw. bloku socjalistycznego. Jego celom w znaczącym stopniu próbowano podporządkować działanie nauki w PRL, od której oczekiwano nie tylko ideologicznej lojalności, ale też konkretnych osiągnięć naukowych: zarówno tych służących konkurującej z zachodnią gospodarce, jak i tych potrzebnych kompleksowi zbrojeniowemu oraz władzom państwowym poszukującym skutecznych sposobów zarządzania społeczeństwem i legitymizacji swojej przywódczej roli zarówno wewnątrz kraju, jak i poza jego granicami. Stąd względnie duży nacisk ówczesnych władz na rozwój dziedzin nauki służących obronności, nauk ścisłych i technicznych oraz wyraźne oczekiwania osiągnięcia międzynarodowej rozpoznawalności przez nauki społeczne, czego wyrazem mogło być m.in. opisywane przez nas wsparcie dla polskiej obecności w IPSA jeszcze za czasów stalinowskich.

Moment załamania się systemu komunistycznego i wyjścia Polski z orbity ZSRR oznaczał jednak porzucenie wcześniejszego projektu modernizacyjnego i marginalizację dawnej nomenklatury na rzecz tradycyjnej inteligenckiej elity zdobywającej wówczas pozycję dominującą w polu władzy. Towarzyszyło temu, o czym pisał sam Antonowicz w swojej znanej książce (Antonowicz 2015), znaczące poszerzenie formalnej autonomii uczelni, a także środowisk akademickich, które osiągnęły praktycznie pełną samorządność (przede wszystkim w rozumieniu prawnym) ${ }^{3}$. Można ten moment interpretować także jako przejęcie kontroli nad nauką przez inteligenckie elity, które wraz z uzyskaniem dominacji politycznej sięgnęły także po znaczące przywileje materialne. Dla akademickiej części inteligenckiej elity oznaczało to w szczególności zaangażowanie się w prywatyzację edukacji i dodatkowo płatną działalność dydaktyczną. Jak przypominali słusznie komentatorzy naszej pracy, działania te w dużym stopniu zniweczyły wcześniej stworzony potencjał naukowy oraz ograniczyły prowadzenie przez znaczną część kadr akademickich konkurencyjnej międzynarodowo działalności naukowej (ograniczając tym samym autonomię pola w wymiarze swobody wyboru tematu badań, czas niezbędny na prawdziwe, pogłębione badania naukowe itd.). Bezpośredni (w szczególności państwowy) nacisk na prowadzenie działalności naukowej, wymiernej w sensie zastosowań czy konkurencyjności międzynarodowej, zmniejszył się jednak znacząco wraz z przejęciem

3 Znaczący stopień formalnej autonomii polskich uczelni od administracji państwowej potwierdzają niektóre badania międzynarodowe, np. kompleksowy raport badawczy o wolnościach akademickich opublikowany przez brytyjskich naukowców Terence Karran i Lucy Mallinson (2017). Jak twierdzimy, autonomia ta w dużym stopniu zabezpiecza pole względem bezpośrednich nacisków politycznych czy też presji na międzynarodową konkurencyjność ze strony państwa. Ze względu jednak na siłę nieformalną polskiego pola władzy i ograniczone finansowanie nauki pole nauk społecznych podlega różnego typu nieformalnym zależnościom, które, jak wspominamy, działają przede wszystkim na poziomie indywidualnym i środowiskowym. 
władzy przez samą inteligencję zdolną teraz do określania samodzielnie formalnych parametrów działania systemu akademickiego.

Elementem tego przejścia była też transformacja gospodarczo-geopolityczna, której znaczenie jest warte podkreślenia i może być uważane za odpowiedź na głos Krzeskiego i Szadkowskiego (2018) postulujący wzmocnienie materialistycznego wymiaru naszej analizy. Tak więc wziąć należy pod uwagę, że znacząca część polskiej gospodarki znalazła się w rękach międzynarodowego kapitału, zaś nowy paradygmat modernizacji przybrał silnie imitacyjny charakter (zob. np. Jasiecki 2013). Zmniejszyła się więc znacząco siła zewnętrznej presji na system akademicki w zakresie tworzenia przezeń innowacyjnych rozwiązań technicznych i intelektualnych. Duża zaś część inteligencji, w tym też istotna grupa zachowująca stanowiska w placówkach naukowych i uczelniach, objęła szeroko rozumiane stanowiska menedżerskie, administracyjne i eksperckie w przedsiębiorstwach i organizacjach będących częścią zachodniego systemu ekonomicznego. Większość z tych podmiotów nastawiona jest, z jednej strony, na obsługę dystrybucji w Polsce wysoko przetworzonych towarów, usług a także idei pochodzących z Zachodu oraz, z drugiej strony, na eksport taniej polskiej siły roboczej i jej wytworów w przeciwnym kierunku. Od systemu akademickiego podmioty te oczekują więc w pierwszej kolejności nie technologicznych innowacji czy konkurencyjnych międzynarodowo idei z zakresu nauk społecznych, ale przede wszystkim wewnątrzkrajowej legitymizacji stosunków społeczno-gospodarczych gwarantującej stabilność uprzywilejowanej części inteligenckiej elity oraz szerszego mechanizmu asymetrycznej relacji z krajami zachodniego rdzenia. Należy zwrócić uwagę, że w tej roli opisywane przez nas autarkiczne polskie nauki społeczne, na czele z politologią, sprawdzają się doskonale. Generują wspomniane już medialne narracje legitymizujące interesy głównych środowisk politycznych inteligenckiej elity, socjalizują pokolenia młodzieży $\mathrm{w}$ uproszczonych być może, ale w pełni wystarczających na potrzeby legitymizacji ładu społecznego modelach zaczerpniętych z głównego nurtu zachodniej liberalnej myśli intelektualnej. Wpisują się one zwykle w szeroko rozumiane ramy teorii modernizacji, legitymizując tym samym status quo zależnej polskiej gospodarki i uprzywilejowaną rolę inteligenckiej elity, w tym elity akademickiej. Ukształtowane w takim kontekście nauki społeczne są jednocześnie zorientowane międzynarodowo, a nawet częściowo kosmopolitycznie, czerpią bowiem szeroko z mainstreamu zachodniej nauki, a jednocześnie są to nauki zdecydowanie „narodowe”4. Wspomnieliśmy już, że dzieje się tak, ponieważ uczestniczą one w bardzo ograniczonym stopniu w międzynarodowych dyskusjach akademickich, podkreślając jednocześnie

${ }^{4}$ Oczywiście w ramach nauk społecznych istnieją pewne różnice (czasem niemałe) w zakresie owego umiędzynarowienia. W ten sposób polska ekonomia i socjologia są znacznie bardziej „kosmpolityczne” niż polska politologia, która, jak napisaliśmy, przejawia większe tendencje „autarkiczne.” 
unikalność polskiej kultury i tradycji, nieprzetłumaczalność na inne języki i konteksty polskiego doświadczenia historycznego oraz wyjątkowość wzniosłej historii polskiej inteligencji. Tymi dyskursami bronią autonomii własnego pola nauk społecznych przed globalną presją, a także uprzywilejowanej roli inteligenckiej elity jako takiej, a w szczególności jako pośrednika pomiędzy zachodnimi gospodarkami a społeczeństwem polskim, czerpiąc z tego statusu zarówno wymierne korzyści materialne, jak i symboliczne.

Jak się wydaje, dobrą ilustracją działania tychże procesów był obserwowany w ostatnim okresie silny środowiskowy opór przeciw wprowadzeniu szeregu przepisów tzw. Ustawy 2.o. Krzeski i Szadkowski (2018), twierdzą, że zarysowana autonomia (autarkia) może zostać rozbita na skutek nowych przepisów, które ma przynieść ta ustawa. Zaznaczmy, że celowo zrezygnowaliśmy z wszelkich przewidywań, gdyż jako socjologowie nie czujemy się w tym względzie kompetentni. Nie jesteśmy przy tym pewni, czy zapowiadane zmiany prawne faktycznie pójdą w kierunku takiego ustawienia kryterium naukowej działalności, który rozbije warunki lokalnej autarkii. Publikacje w światowych czasopismach z zakresu nauk społecznych autorstwa polskich badaczy są jak na razie rzadkością (tyczy się to, co może dziwić, także osób z tytułem doktora habilitowanego, a nawet profesorów), trudno się więc spodziewać, żeby środowisko zaczęło funkcjonować wedle takich zasad. Raczej należy oczekiwać omijania nowych reguł, wprowadzenia kolejnej zastępczej listy czasopism (w rodzaju ERIH) oraz, jak to już obserwowaliśmy w procesie konsultacji ustawy, osłabiania ustawowej presji na uwzględnianie międzynarodowych kryteriów oceny dorobku naukowego. Co równie ważne, ustawa nie zmieni, jak się wydaje, fundamentów autonomii pola naukowego w Polsce, która opiera się na roli samorządowych de facto ciałach pozwalających elicie akademickiej na arbitralną w dużym stopniu dystrybucję kluczowych zasobów w polu, jakimi są przede wszystkim stopnie i tytuły naukowe oraz inne uprawnienia indywidualne i instytucjonalne. Obserwacja dotychczasowych praktyk w tym zakresie, które są udziałem Centralnej Komisji do Sprawy Tytułów i Stopni, rad wydziałów, senatów czy różnego typu komisji, w szczególności w zakresie nauk politycznych, pokazuje, że wymogi takie jak te dotyczące „oryginalności” czy „znaczącego wkładu w dyscyplinę" traktują one całkowicie arbitralnie. Często robią to w oderwaniu od jakichkolwiek zobiektywizowanych kryteriów, a czasem nie licząc się nawet z formalnymi wymogami ustawowymi dotyczącymi np. doświadczeń międzynarodowych czy innych osiągnięć wymaganych dla przyznania kolejnych stopni i tytułów, a także różnego rodzaju uprawnień i stanowisk 5 . Ich rozstrzygnięcia

5 Wiele przykładów ignorowania przez Centralną Komisję ds. Tytułów i Stopni, rady wydziałów oraz poszczególnych recenzentów wymogów ustawowych dotyczących habilitacji czy profesur dostarcza blog http://habilitant2012.blox.pl/ 
są jednak kluczowe i nie ma podstaw, by w przyszłości taka praktyka działania tych ciał samorządowych uległa zasadniczej zmianie, co pozwoli na utrzymanie opisywanego przez nas stanu autonomii/autarkii pola i zmarginalizowanie administracyjnej presji na jego internacjonalizację.

Krzeski i Szadkowski (2018) podnoszą także szalenie interesującą kwestię relacji między poszczególnymi strefami systemu światowego - centrum, peryferiami i półperyferiami, argumentując, że pośrednicząca rola tych ostatnich ulega dziś podważeniu. Faktycznie, półperyferie polskie przed 1989 rokiem pełniły dość wyraźnie istotną rolę pośredniczącą wobec innych państwa regionu (np. podręcznik do socjologii polityki Jerzego Wiatra, wydany także w ZSRR, pełnił istotną rolę w transferze idei zachodnich do tego kraju; podobnie rzecz się miała z częstymi odniesieniami do autorów polskich w naukowym czasopiśmiennictwie czechosłowackim), dzisiaj nie ma to już większego znaczenia. Peryferie zdają się już nie potrzebować tak wyraźnie półperyferyjnego pośrednika, chociaż należy zauważyć wyraźną regionalizację nauki (np. w ramach Unii Europejskiej, zob. Heilbron, Boncourt i Timans 2018), która uzupełnia procesy jej globalizacji. Można też zwrócić uwagę, że w pewnych aspektach pośredniczące role charakterystyczne dla nauki półperyferyjnej są w dalszym ciągu wyraźne w polu polskiej politologii. Dotyczy to przede wszystkim umiędzynarodowienia edukacji. I tak na przykład, jak udokumentowano to w tomie pod redakcją Tomasza Domańskiego, Alicji Stępień-Kuczyńskiej i Agaty Włodarska-Frykowskiej (2016), polskie uczelnie, a w szczególności wydziały nauk politycznych przyciągają coraz większe rzesze studentów z krajów na dalszych w stosunku do Polski orbitach peryferyjności wobec Europy Zachodniej, w szczególności z Ukrainy czy Turcji. Jak się należy domyślać, chodzi głownie o studentów z domów uboższej klasy średniej tych krajów, dla których polskie uczelnie oferują wykształcenie bardziej dostępne cenowo od uniwersytetów zachodnich, choć mniej prestiżowe, to mające status „europejskości” dzięki przynależności Polski do Unii Europejskiej. Warto też zwrócić uwagę, że polskie czasopisma naukowe, szczególnie te wydawane przez ośrodki regionalne, są często atrakcyjnym miejscem publikacji dla politologów z Ukrainy czy Słowacji, którzy nie są w stanie umieścić swych tekstów w pismach zachodnich. Często publikacje te włączone są w sieci swoistej wymiany, które również polskim politologom pozwalają na choćby formalne spełnienie wymogów umiędzynarodowienia ich dorobku. Z pewnością jednak zagadnienie to wymaga dalszych badań.

Antonowicz (2018) twierdząc, że słabością naszej pracy jest też brak scenariuszy przyszłości, sugeruje, iż uważamy że pozycja polskiej nauki, a w szczególności nauk politycznych jest w zdeterminowana przez półperyferyjne położenie Polski. Poprzez porównania z innymi krajami, co zostało przedstawione w książce, 
wskazujemy, że obecny stan względnej izolacji polskiej politologii wobec międzynarodowego obiegu akademickiego nie jest wcale charakterystyczny dla wszystkich krajów regionu dzielących z Polską w dużym stopniu zarówno położenie geopolityczne, jak i zasobność materialną. Dobrymi przykładami pokazującymi alternatywne scenariusze rozwoju dyscypliny są choćby Czechy czy Estonia. Jak się jednak wydaje, jednym z kluczowych czynników różniących te kraje od Polski, i w pewnym stopniu tłumaczących odmienności trajektorii pól politologicznych, jest wzmiankowana tu już odmienna rola tradycyjnych elit inteligenckich. Podczas gdy w Polsce ich rola może być postrzegana jako dominująca i zdołały one dzięki temu podporządkować sobie większość pola akademickiego, we wspomnianych krajach sąsiednich nie pełnią one tak istotnej roli, a o wiele słabsze społeczno-politycznie środowisko nauk społecznych musiało tam pogodzić się z silnym naciskiem pola władzy na internacjonalizację i dostosowanie się do międzynarodowych standardów oceny pracy naukowej. Naszym celem nie było wypracowanie możliwych scenariuszy zmian, a raczej pewnego spojrzenia na pole nauk społecznych, które pozwoliłoby na rekonstrukcję kluczowych mechanizmów jego funkcjonowania. Na podstawie naszych obserwacji możemy jednak przypuszczać, że trudno będzie oczekiwać znaczącego przyspieszenia dynamiki zmian w obszarze polskich nauk społecznych, biorąc pod uwagę nawet nie tylko półperyferyjny status kraju, ale i trwałość hierarchii elit społecznych oraz roli nauk społecznych dla tradycyjnych polskich elit.

\section{Literatura}

Antonowicz, D. (2015). Między siłą globalnych procesów a lokalną tradycją: Polskie szkolnictwo wyższe $w$ dobie przemian. Torun: Wydawnictwo Naukowe UMK.

Antonowicz, D. (2018). Uciec, ale dokąd.... Nauka i Szkolnictwo Wyższe. 1(51): 173-179.

Bourdieu, P. (1996). The state nobility: Elite schools in the field of power. Stanford, CA: Stanford University Press.

Bourdieu, P. (2001). Reguty sztuki: geneza i struktura pola literackiego, przeł. A. Zawadzki. Kraków: Universitas.

Bourdieu, P. (2006). Medytacje pascaliańskie, przeł. K. Wakar. Warszawa: Oficyna Naukowa. Bourdieu, P. (2009). O telewizji: Panowanie dziennikarstwa, przeł. A. Ziółkowska i K. Sztandar-Sztanderska. Warszawa: Wydawnictwo Naukowe PWN.

Burawoy, M. (2005). For Public Sociology. American Sociological Review. 70(1): 4-28.

Burawoy, M. (2018). The Poverty of Philosophy: Marx Meets Bourdieu. W: T. Medvetz i J.J. Sallaz (red.), The Oxford Handbook of Pierre Bourdieu. Oxford: Oxford University Press. Casanova, P. (2017). Światowa republika literatury, przeł. E. Gałuszka i A. Turczyn. Kraków: Wydawnictwo UJ. 
Dębska, H. (2016). Strategia wielopozycyjności w półperyferyjnym polu prawnym: Homo Academicus na rynku. W: T. Zarycki (red.), Polska jako peryferie (221-240). Warszawa: Wydawnictw Naukowe „Scholar”.

Domański, T., Stępień-Kuczyńska, A. i Włodarska-Frykowska, A. (red.). (2016). Internacjonalizacja polskich ośrodków politologicznych. Łódź: Wydawnictwo UŁ.

Gingras, Y. (2002). Les formes spécifiques de l'internationalité du champ scientifique. Actes de la recherche en sciences sociales. 141-142 : 31-45.

Gingras, Y. (2013). Les dérives de l'évaluation de la recherche du bon usage de la bibliométrie. Paris: Raisons d'agir.

Heilbron, J., Boncourt, T. i Timans, R. (2018). The European Research Area in the Social and Human Sciences: Between National Closure and American Hegemony. W: J. Heilbron, G. Sora i T. Boncourt (Red.), The Social and Human Sciences in Global Power Relations (153-181). London: Palgrave Macmillan.

Jasiecki, K. (2013). Kapitalizm po polsku: Między modernizacją a peryferiami polskimi. Warszawa: Wydawnictwo IFiS PAN.

Karran, T. i Mallinson, L. (2017). Academic Freedom in the U.K.: Legal and Normative Protection in a Comparative Context. Report for the University and College Union. Lincoln: University of Lincoln.

Kostera, M. (2018). Nieodparta erotyka kości. https://nowyobywatel.pl/2018/o6/o7/nieodparta-erotyka-kosci/ [10.06.2018].

Krzeski, J. i Szadkowski, K. (2018). Między autonomią a podporządkowaniem: Problemy metodologiczne analizy (pół)peryferyjnych systemów nauki. Nauka i Szkolnictwo Wyższe. 1(51): 161-171.

Kwiek, M. (2012). Changing higher education policies: From the deinstitutionalization to the reinstitutionalization of the research mission in Polish universities. Science and Public Policy. 39(5): 641-654.

Sapiro, G. (2012). Traduire la littérature et les sciences humaines: conditions et obstacles. Paris: Ministère de la culture, Secrétariat général, Département des études, de la prospective et des statistiques, DEPS.

Wallerstein, I.M. (2004). Koniec świata jaki znamy, przeł. M. Bilewicz i A.W. Jelonek. Warszawa: Wydawnictwo Naukowe „Scholar”.

Wallerstein, I.M. (2011). Capitalist agriculture and the origins of the European world-economy in the sixteenth century. Berkeley: University of California Press.

Warczok, T. i Zarycki, T. (2014). Bourdieu recontextualized: Redefinitions of western critical thought in the periphery. Current Sociology Current Sociology. 62(3): 334-351.

Warczok, T. i Zarycki, T. (2016). Gra peryferyjna: Polska politologia w globalnym polu nauk społecznych. Warszawa: Wydawnictwo Naukowe „Scholar”.

Zarycki, T. i Warczok, T. (2014). Hegemonia inteligencka: Kapitał kulturowy we współczesnym polskim polu władzy - perspektywa „długiego trwania. Kultura i Społeczeństwo. 4: 27-49. 


\title{
Dimensions of dependence and forms of autonomy and autarchy of Polish political science: Response to comments
}

\begin{abstract}
This article is one of the voices in the discussion on the semi-peripheral nature of knowledge production systems, inspired by the publication of Gra peryferyjna by Tomasz Warczok and Tomasz Zarycki. The authors answer two polemical voices in the discussion by focusing on the dangers of the materialistic correction of Pierre Bourdieu's theory and the hegemonic position of the intelligentsia as a factor shaping the Polish field of social sciences.
\end{abstract}

KEYWORDS: gra peryferyjna, centers, peripheries, social sciences, Bourdieu, Wallerstein

CYTOWANIE: Warczok, T. i Zarycki, T. (2018). Wymiary zależności a formy autonomii i autarkii polskiej politologii: Odpowiedź na komentarze. Nauka i Szkolnictwo Wyższe. 1(51): 183-196. DOI: 10.14746/nisw.2018.1.9.

TOMASZ WARCZOK - socjolog, adiunkt w Instytucie Filozofii i Socjologii Uniwersytetu Pedagogicznego im. KEN w Krakowie, członek Zespołu Studiów nad Peryferyjnością w Instytucie Studiów Społecznych im. Profesora Roberta Zajonca Uniwersytetu Warszawskiego. Publikował m.in. w pismach: Current Sociology, Polish Sociological Review, Kultura i Spoleczeństwo czy Studia Socjologiczne. Ostatnio współautor książek: Granice symboliczne: Studium praktyk kulturowych na przykładzie działań zawodowych pracowników socjalnych (2013) oraz Literatura polska po 1989 roku w świetle teorii Pierre’a Bourdieu (2014).

TOMASZ ZARYCKI - socjolog, geograf społeczny, profesor i dyrektor w Instytucie Studiów Społecznych im. Profesora Roberta Zajonca Uniwersytetu Warszawskiego. Publikował m.in. w pismach: Current Sociology, Geoforum, East European Politics and Societies, Europe-Asia Studies czy Theory and Society. Autor m.in. książek: Ideologies of Eastness in Central and Eastern Europe (2014) oraz (wspólnie z Rafałem Smoczyńskim) Totem inteligencki: Arystokracja, szlachta i ziemiaństwo w polskiej przestrzeni społecznej (2017). 